\title{
Geographical pattern and historical demography of Midday gerbil Meriones meridianus (Gerbillidae, Rodentia) inferred from the sequences of the mitochondrial DNA control region
}

\author{
Guiyi Zou, Lizhi Zhou, Xiangdong Zha, Baowei Zhang, \\ Tianbiao Zhao, Jun Liang
}

\begin{abstract}
In order to examine DNA sequence variation, the cause of geographic patterns and historical demography of populations, we sampled 69 individuals of Midday gerbil Meriones meridianus. Among the comparable sequences of 396 bp, 52 haplotypes were defined, 97 nucleotide sites were variable $(24.5 \%$ in the full sequences). Phylogenetic tree constructed using the neighbor-joining (NJ) of haplotypes demonstrated three clades associated with geographical regions. There were no shared haplotypes found among regions. Time of gene divergence between three clades of Midday gerbil was estimated by mean nucleotide difference, suggesting the divergence of three clades during the Middle Pleistocene. The pattern of phylogenetic discontinuity is a result of both factors which is associated with the uplift of the Qinghai-Tibet Plateau and climate change in Quaternary ice ages. We also examined the historical demography of the clades using stepwise and exponential expansion models, both of which indicated recent rapid population growth. The pairwise mismatch distribution suggested a pattern of population expansion. The population expansion analysis indicated that the present distribution of the population was probably shaped through the rapid range expansion during the last interglaciation stage from the refugium.
\end{abstract}

KEY WORDS: Midday gerbil, mitochondrial DNA control region, phylogeography, historical demography.

Guiyi Zou, Lizhi Zhou, Xiangdong Zha Baowei Zhang \& Jun Liang [corresponding author: zhoulz@ahu.edu.cn], Anhui Key Laboratory of Ecological Engineering and Biotechnology, Institute of Biodiversity and Wetland Ecology, School of Life Science, Anhui University, Hefei 230039, China; Tianbiao Zhao, Inner Mongolia Center for Endemic Diseases Control and Research, Huhhot 010031, China.

\section{Географическая изменчивость и историческая демография полуденной песчанки (по данным анализа последовательностей контрольного региона митохондриальной ДНК)}

\author{
Guiyi Zou, Lizhi Zhou, Xiangdong Zha, Baowei Zhang, \\ Tianbiao Zhao, Jun Liang
}

РЕЗЮМЕ. Изучена изменчивость контрольного региона у 69 особей полуденной песчанки Meriones meridianus. Среди сравниваемых последовательностей в 396 пн, 97 сайтов были вариабельными и обнаружено 52 гаплотипа. На филогенетическом дереве, построенном по методу ближайшего соседа, четко выделяются три кластера, соответствующие географическим регионам. Наиболее вероятное время дивергенции между тремя кладами полуденной песчанки, оцененное по средним генетическим дистанциям - средний плейстоцен. Историческая демография каждой клады проанализировали с использованием моделей пошагового и экспоненциального роста. Обе модели указывают на недавний быстрый рост численности и на то, что современное распространение популяций полуденной песчанки вероятней всего результат быстрого расширения ареала в течение последнего межледниковья из рефугиума.

КЛЮЧЕВЫЕ СЛОВА: полуденная песчанка, митохондриальная ДНК, контрольный регион, филогеография, историческая демография. 


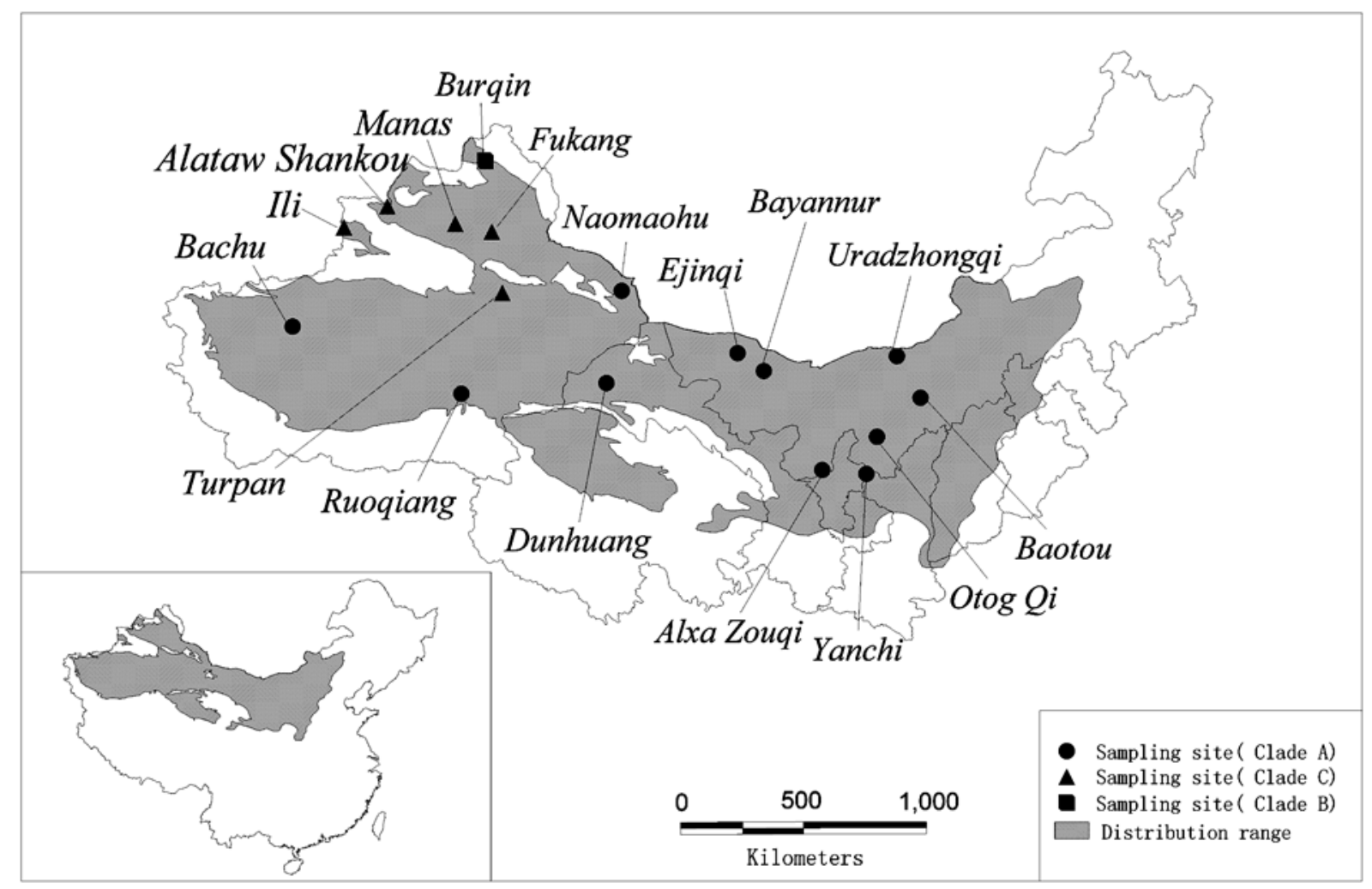

Figure 1. The sampling sites in the range of Midday gerbil. Clade A, Clade B, and Clade C indicate the same meanings as those in Fig. 2. Map data are from Chinese Resources and Environment Database (1: 4000 000, Institute of Geographic Sciences and Natural Resources Research, CAS, 1998).

\section{Introduction}

Geographic barriers affect the species genetic variation of the spatial distribution pattern (Avise et al., 1987; Avise, 2000). While during the Pleistocene, glacial advances were interspersed with warm interglacials in cycles that influenced the spatial distribution and demography of species (Galbreath, 2004). The Qinghai-Tibet Plateau uplift caused great climatic changes and deserts developed in Inner Mongolian and Xinjiang regions since Pleistocene (Zhang et al., 2000). With glacial cycles in Tianshan and Altai mountains, climatic zones migrated north and south, resulting in evolution, differentiation and migration of the fauna (Ma et al., 1987). These geological events had a great influence on the fauna in China (Zhang et al., 2000). Thermoxerophilous rodents are dominant in Inner Mongolia and Xinjiang regions of China (Zhou, 2002). The expanding process of their distribution had important significance on the evolution of the fauna of this biogeographic region.

The Midday gerbil (Meriones meridianus) is widely distributed in China, Mongolia, Kazakhstan, and Tajikistan. In China their ranges cover Xinjiang, Gansu, Ningxia, Qinghai, Inner Mongolia, Shanxi, and Henan (Fig. 1). They are hand in glove with such more various desert and semi-desert habitats that could be regarded as an important biodiversity indicator in the arid landscape. Based on pelage coloration and morphological characters of skulls and tails, this species was classified into 7 subspecies in China (Luo et al., 2000), which implied large geographical variation of morphology.

According to the available data of species distribution, Midday gerbil might enter China from Africa, southwest of Asia and Turan Plain lowland via Alashan (Zhou et al., 2001). For most of the past century, researches have had to rely on the paleontological records in order to reconstruct the phylogeographic patterns. However, fossil record provides only little information about this species. More recently, molecular methods to detect genetic variation within species have led to exciting advances in studies of the historical biogeography.

Mitochondrial DNA polymorphism is commonly used to reveal phylogenetic and phylogeographic relationships between populations of a species (Avise et al., 1987). The control region (CR), a unique noncoding nucleotide sequence, is the most variable portion of mtDNA in mammals (Saccone et al., 1993). In this study, we used the control region to determine the geographic patterns of genetic variation. We performed phylogeographic and historical demographic analyses to better understand the patterns of geographic distributions of evolutionary lineages and the historical process 
Table 1. Samples of Midday gerbil.

\begin{tabular}{|c|c|c|}
\hline Sampling regions & Sampling site & Specimen code \\
\hline \multirow{6}{*}{ Inner Mongolia } & Ejinqi & EQ1, EQ2, EQ3, EQ4, EQ5, EQ6, EQ7 \\
\hline & Bayannurmeng & BY1, BY2 \\
\hline & Uradzhongqi & WZ1, WZ2, WZ3, WZ4, WZ5, WZ6, WZ7 \\
\hline & Alxa Zouqi & LJ1, LJ2, LJ3, LJ4, LJ5, LJ6 \\
\hline & Otog Qi & ETK1, ETK2, ETK3, ETK4, ETK5 \\
\hline & Baotou & BT1 \\
\hline \multirow{9}{*}{ Xinjiang } & Turpan & TL1, TL2, TL3, TL4, TL5 \\
\hline & Alataw Shankou & AL1, AL2, AL3, AL4 \\
\hline & Ili & YL1, YL2, YL3 \\
\hline & Manas & MS1, MS2, MS3 \\
\hline & Fukang & FK1, FK2 \\
\hline & RuoQiang & RQ1, RQ2, RQ3, RQ4, RQ5, RQ6, RQ7 \\
\hline & Naomaohu & NH1 \\
\hline & Burqin & $\mathrm{BJ} 1, \mathrm{BJ} 2, \mathrm{BJ} 3$ \\
\hline & Bachu & $\mathrm{BC} 1, \mathrm{BC} 2, \mathrm{BC} 3, \mathrm{BC} 4, \mathrm{BC} 5, \mathrm{BC} 6$ \\
\hline Gansu & Dunhuang & DH1 \\
\hline Ningxia & Yanchi & $\mathrm{YC} 1, \mathrm{YC} 2, \mathrm{YC} 3, \mathrm{YC} 4$ \\
\hline Russia & Kalmykia & Russia1 \\
\hline
\end{tabular}

leading to the present distribution of Midday gerbil in arid regions of China.

\section{Materials and methods}

Sampling. We examined a total of 68 individuals of Midday gerbil from 18 localities in China (Tab. 1) and one specimen from Russia (Kalmykia, $46^{\circ} 04^{\prime} \mathrm{N}, 46^{\circ} 18^{\prime}$ E). Genomic DNA was extracted from $95 \%$ ethanol preserved tissues using standard procedures (Sambrook et al., 1989; Oshida et al., 2005).

Laboratory techniques. We sequenced $396 \mathrm{bp}$ of the control region for 69 individuals. The first $22 \mathrm{bp}$ of this sequence are included in the highly conserved tRNApro gene at 5' end of the control region, and about 50-100bp at 3' end of the sequence are included in the central conserved block of the control region (Bibb et al., 1981; Taberlet, 1996; Zheng et al., 2003). The primers used were L15933 (5'-ATTACA CTGGTCTTGTAAACCGGAAATG-3') and TDKD (5'-CCTGAAGTAGGAACCAGATG-3'; Kocher et al., 1993). The conditions for the PCR were as follows: initial denaturation for $50 \mathrm{~s}$ at $96^{\circ}, 40$ cycles with denaturation at $95^{\circ}$ for $30 \mathrm{~s}$, annealing at $55^{\circ}$ for $1 \mathrm{~min}$, and extension at $72^{\circ}$ for $1 \mathrm{~min}$, followed by a final extension step at $72^{\circ}$ for $10 \mathrm{~min}$. Polymerase chain reaction (PCR) was conducted in a total volume of $50 \mathrm{ul}$ containing $1 \times \mathrm{PCR}$ buffer, $2.0 \mathrm{mM} \mathrm{MgCl} 2,0.2 \mathrm{mM}$ of each dNTP, $1.0 \mathrm{uM}$ of each primer, 1 unit of Taq DNA polymerase (Hoffmann-LaRoche, Inc.), and $1-2 \mu \mathrm{L}$ DNA in each case. Nucleotide sequences were determined by using automated sequencers ABI 3730XL (Sangon, China).

Sequence alignment and phylogenetic analysis. Sequences were aligned using Clustal X (Thompson et $a l ., 1997)$ and visually checked. Initial sequence comparisons and measures of variability were performed using MEGA3.0 (Kumar et al., 2004), and unique haplotypes were identified using DAMBE (Xia \& Xie, 2001). Phylogenetic trees were reconstructed using NJ method. We used bootstrap analysis with 1000 replicates to evaluate support for the branches, as implemented in Mega3.0. Sequences of Clawed jird (Meriones unguiculatus) was used as outgroup.

Time divergence. Initial times of the mtDNA control region divergence between the clades were estimated by $d x y=2 u t$, where $d x y$ is the mean nucleotide difference between haplotypes of two clades, $t$ is time since divergence. Notice that $\mathrm{u}=\mu \mathrm{mT}$ is the mutation rate for the entire DNA sequence under study, where $\mathrm{mT}$ is the number of nucleotides of the sequence, and $\mu$ is the mutation rate per nucleotide (Rogers \& Harpending, 1992). For the control region sequence of this study $\mathrm{mT}$ is 396 ; $\mu$ is $12.4 \%$ per million years (Ma) (Pierpaoli et al., 1999). To correct the discrepancy between "gene divergence" and "population divergence" due to the presence of ancestral polymorphism in populations (Edwards \& Beeli, 2000), we corrected the molecular di- 


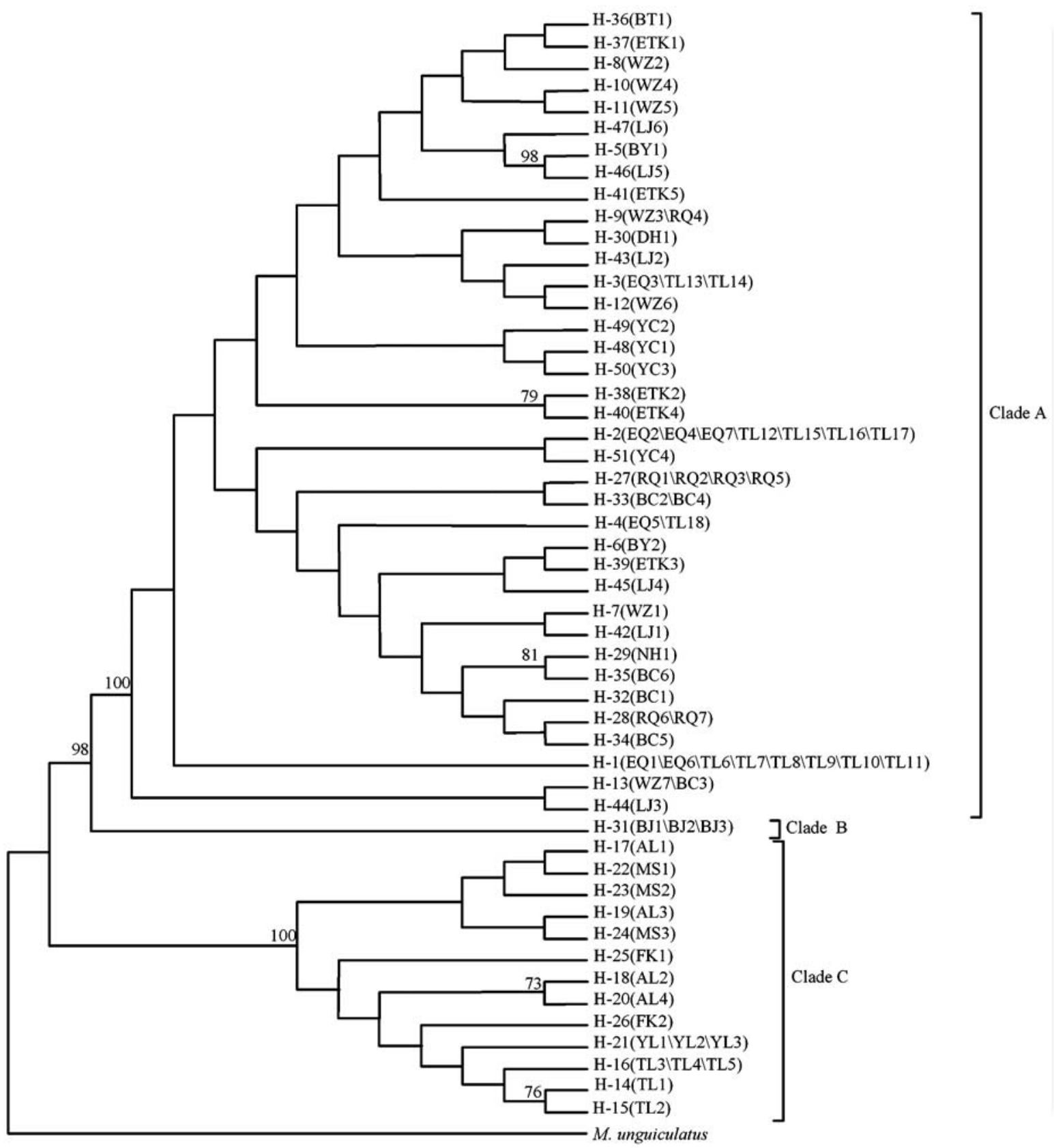

Figure 2. Neighbour-joining trees for mitochondual DNA from control region haplotypes. Bootstrap support of $>70 \%$ in 1000 replicates is shown above branches. Clawed jird Meriones unguiculatus is used as outgroup.

versity by $\mathrm{dA}=\mathrm{dxy}-1 / 2 \mathrm{dx}+\mathrm{dy}$ (Zheng et al., 2003; Herron et al., 2005), where $\mathrm{dx}$ and dy are mean molecular differences of the clades, respectively; $\mathrm{dA}$ is corrected molecular difference between two clades. The initial periods of gene divergence between the clades were also estimated by $\mathrm{dA}=2$ ut (Nei \& Li, 1979).

Historical demography. With the program ARLEQUIN3.0 (Excoffier et al., 2006), we computed frequencies of pairwise difference between haplotypes (the mismatch distribution) to evaluate the hypothesis of recent population growth. Additionally, Fu's test of neutrality was performed for sequences within each of lineages (Fu, 1997). Significant negative values of Fu's statistics can be interpreted as a signature of population expansion. ARLEQUIN also uses a nonlinear least squares approach to estimate parameters for a stepwise growth model (Zheng et al., 2003): $\theta_{0}=2 \mu \mathrm{N}_{0}$ (before expansion), $\theta_{1}=2 \mu \mathrm{N}_{1}$ (after expansion) and $\mathrm{t}=2 \mathrm{ut}$ (time of expansion). $\mathrm{N}_{0}$ and $\mathrm{N}_{1}$ are effective population size of females before and after expansion, respectively. Where $t$ is estimated by MDA, $t$ is time since expansion and $\mathrm{u}$ is the same as described above. For a model of 


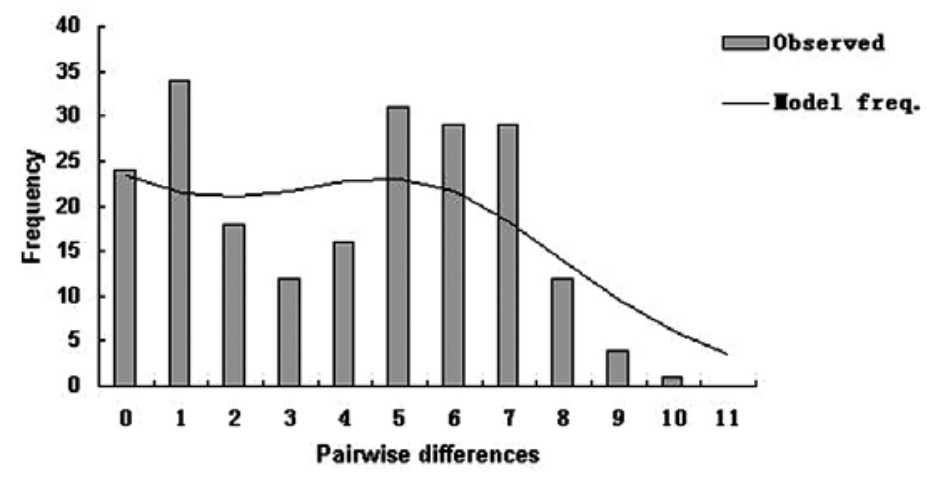

Figure 3. Mismatch distribution for two phylogroups of Midday gerbil. Bars indicated the distribution of pairwise differences among haplotypes within clades. The black line depicted the theoretical distribution as expected under the hypothesis of sudden expansion. Designations of clades as in Fig. 2.

A—clade A haplotypes; B—clade C haplotypes.

exponential expansion, we used the program FLUCTUATE1.3 (Kuhner et al., 1998), based on coalescence and maximum likelihood to estimate a present-day value of $\theta(\theta=2 \mu \mathrm{NF})$ and exponential growth rate $(\mathrm{g})$. Here $\mathrm{u}$ is also the same as described above and NF is effective population size of females.

\section{Results}

Mitochondrial DNA variation. Among the total 69 sequences examined, 52 distinct haplotypes were identified. In total, 97 variable sites were found $(24.5 \%$ of the entire sequence), including 76 Parsimony-informative sites and 4 insertions/deletions. Base composition of mtDNA control region sequences (A:29.4\%, C:25.8\%, G:13.0\%, T:31.8\%) was consistent with other mammalian mtDNA control region sequences.

Phylogenetic reconstruction. The NJ tree is illustrated in Fig. 2 to show the relationship between haplotypes. M. meridianus comprised three clades (clade A, clade B, and clade $\mathrm{C}$ ). The clade A included of haplotypes from Baotou, Otog Qi, Uradzhongqi, Alxa Zouqi, Bayannurmeng, Ejinqi, Yanchi, RuoQiang, while the clade B comprises of haplotypes from Burqin and Russia. As for the clade C, it containes haplotypes from Ili, Alataw Shankou, Manas, Turpan, and Fukang.

Demographic inferences. The mismatch distribution of clade $\mathrm{A}$ and clade $\mathrm{C}$ is consistent with the sudden expansion model. Similarly, other tests of change in population size, clade $\mathrm{A}(\mathrm{Fs}=-19.97, \mathrm{P}=0.00)$ and clade $\mathrm{C}(\mathrm{Fs}=4.51, \mathrm{P}=0.02)$ indicated sudden expansion. Only the ages of expansion in clade $\mathrm{A}$ and clade $\mathrm{C}$ were described because samples of clade B (two haplotypes) were under-represented. Mismatch distributions of clade A, clade $\mathrm{C}$ and entire haplotypes are illustrated in Fig. 3. The values of $\tau$ were 11.475 in clade $A$ and 6.697 in clade $\mathrm{C}$ (Tab. 2), which gave the estimated ages of expansion to be $0.117 \mathrm{Ma}$ and $0.068 \mathrm{Ma}$, respectively. All estimates of $\theta_{1}$ derived from the stepwise growth model were at least several times higher

Table 2. Estimated parameters of population expansion for (A) exponential and (B) stepwise expansion models for Midday gerbil

A. Exponential expansion model*

\begin{tabular}{|l|c|c|c|c|}
\hline Clade & Sample size & Haplotype size & $\theta(\mathrm{SD})$ & $\mathrm{g}(\mathrm{SD})$ \\
\hline A & 47 & 37 & $0.4714(0.066)$ & $214.7199(18.487)$ \\
\hline C & 17 & 13 & $0.0694(0.015)$ & $310.4146(61.448)$ \\
\hline Total & 68 & 52 & $0.2311(0.022)$ & $35.8701(5.467)$ \\
\hline
\end{tabular}

B. Stepwise expansion model**

\begin{tabular}{|l|c|c|c|}
\hline Clade & $\mathrm{t}=2 \mathrm{ut}$ & $\theta_{0}=2 \mu \mathrm{N}_{0}$ & $\theta_{1}=2 \mu \mathrm{N}_{1}$ \\
\hline $\mathrm{A}$ & $11.475(6.684,13.322)$ & $0.079(0.000,2.575)$ & $89.189(51.221,99999.000)$ \\
\hline $\mathrm{C}$ & $6.697(2.396,1.559)$ & $0.000(0.000,2.677)$ & $79.140(34.559,99999.000)$ \\
\hline Total & $4.559(1.559,30.150)$ & $22.976(0.000,48.380)$ & $387.025(32.826,99999.000)$ \\
\hline
\end{tabular}

* Population parameters under the exponential model are given as maximum likelihood estimates (+ SD).

** Population parameters under the stepwise model are given as estimates $(95 \%$ confidence limits). 
Table 3. Divergence time (Ma) estimates for Midday gerbil clades based on mean nucleotide differences, and corrected mean nucleotide differences. Mean nucleotide differences between clades is above diagonal, Corrected mean nucleotide differences between clades is below diagonal, and estimated divergence time (Ma) is in the parentheses.

\begin{tabular}{|l|c|c|c|}
\hline Clade & A & B & C \\
\hline A & - & $38.4(0.38)$ & $54.9(0.57) 52.1(0.52)$ \\
\hline B & $31.6(0.32)$ & - & \\
\hline C & $46.8(0.47)$ & $47.8(0.48)$ & - \\
\hline
\end{tabular}

than the corresponding $\theta 0$ values (Tab. 3 ). Among the $g$ values estimated in FLUCTUATE, all were significantly different from zero according to likelihood-ratio test (Tab. 2). Maximum-likelihood estimates of g were positive in all cases, indicating exponential growth of the populations. Estimates of divergence times resulting from mean nucleotide differences and corrected mean nucleotide differences were broadly similar (Tab. 2). The values of dxy between the clades ranged from 38.4-54.9 (Tab. 3), which corresponded to an initial gene divergent time of 0.39-0.57 Ma. Similarly, the values of dA between the clades ranged from 31.647.8, which corresponded to an initial gene divergent time of $0.32-0.48 \mathrm{Ma}$. Divergence times estimated by mean nucleotide differences and corrected mean nucleotide differences of three clades suggests that divergence of the three clades may have occurred in the Middle Pleistocene.

\section{Discussion}

Phylogeographic structure. The occurrence of three distinct clades of Midday gerbil in China (Fig. 2) implies some important factors that formed the geographical patterns in arid regions of China. To elucidate the possible events that caused the observed patterns, it is important to determine the age of the split. Based on the divergence rate of the control region were $24.8 \%$ per million years (Ma) (Pierpaoli et al., 1999), the divergence time for the Midday gerbil's lineages was estimated to be $0.39-0.57 \mathrm{Ma}$.

Geographic barriers affect the species genetic variation of the spatial distribution pattern (Avise et al., 1987; Avise, 2000). Mountains also might create barriers to gene flow because they are believed to be major zoogeographical barriers associated with evolutionary divergence (Bos \& Sites, 2001; Roslin, 2001).The Qinghai-Tibet Plateau uplift is an important factor that affected the climate and the environment of China in the Quaternary period. Apparently, this event has caused a genetic division in other taxa from this region (Zhang et al., 2000; Carsten et al., 2004; Steele et al., 2005). The uplift of the QinghaiTibet plateau has produced repetitive patterns of genetic diversification across multiple taxa (Qu, 2005). Prominent genetic gap defined deep allopatric lineag- es, probably originated from long-term extrinsic barriers to gene exchange (Avise, 2000). Here, we assume that the mountain ranges within the present distribution range constitute barriers to gene flow that have led to population differentiation. However, Tianshan Mountains is discontinuous in Xinjiang of China where there are several valleys and basins such as Ili Valley in the west and Turpan Basin in the east (Li et al., 2006). Focusing the attention on Clade C, "TL" population is closer to "YL" population (Figs 2 and 3 ). There is no significant genetic divergence existing among regional groups separated by mountain ranges, as implies that Tianshan Mountains is not an insurmountable barrier to Midday gerbil.

The complex climatic oscillations in the Pleistocene are thought to have been crucial in shaping population structure and phylogeographic patterns of many species (Hewitt, 2000), and the glacial history of a region plays a substantial role in shaping intraspecific variation (Hewitt, 1999). Due to isolation during glacial maxima, patterns of population differentiation and phylogeography are very evident in some species, such as the Shorttailed shrew, Blarina brevicauda (Brand \& Orti, 2003) and Long-tailed vole, Microtus longicaudus (Conroy \& Cook, 2000). In eastern Asia, frequent glaciations during the Pleistocene have left a significant genetic signature in several species (Mahmut et al., 2002; Li et al., 2003, 2005; Qu et al., 2005). The deep divergence between the three main groups was caused by prolonged periods of isolation, possibly as a result of Pleistocene glacial cycles. It is possible that the presentday distribution of Midday gerbil stemmed directly from postglacial colonization. Fragmentation in an aridadapted species such as Midday gerbil may have resulted in isolation in different refugia during the uplift of Qinghai-Tibet plateau led to phylogeographical divergence in this species.

Historical demographic. Glaciers retreated with climate warming, sometimes disappearing entirely, thus creating opportunities for postglacial expansion (Galbreath, 2004). The exponential expansion model indicated a rapid increase in effective population size for both clades. Growth rates $(\mathrm{g})$ indicate rapid expansion. These results are consistent with expectations of a Pleistocene population expansion over formerly glaciated areas (Tab. 2). 
Unimodal mismatch distributions, significant negative values of Fu's Fs for Clade A and Clade C support sudden population expansion after genetic isolation (Fig. 3, Tab. 2) (Fu, 1997). In the stepwise expansion model, estimated effective population size after expansion $(\theta 1)$ is several times higher than before expansion $(\theta 0)$. The dating of the expansions based on $\tau$ - values of 11.475 and 6.697 , and a mutation rate $(\mu)$ of $12.4 \%$ per million years (Pierpaoli et al., 1999), the expansion time of Clade $\mathrm{A}$ and Clade $\mathrm{C}$ was estimated to date to 0.118 and 0.064 million years ago. These results indicated that population of Clade $\mathrm{A}$ and Clade $\mathrm{C}$ expanded following the retreating ice sheets. Studies revealed that the retreat of ice sheets provided an opportunity for organisms to expand (Conroy \& Cook, 2000; Brand \& Orti, 2003; Ernesto et al., 2006). The major increases in effective population size were associated the most recent glacial retreat (Pielou, 1991), however our result also suggest that the case of Midday gerbil was associated with a longer period of geological history. It should be emphasized that these estimate of expansion time were based on a mutation rate $(\mu)$ of $12.4 \%$ per million years. A different calibration of mutation rate would certainly affect the estimate of expansion time. Furthermore, the stepwise expansion scenario contains a very simplified reflection of the demographic history. The expansion indicated by the models may actually have consisted of a series of demographic fluctuations over hundreds of thousands of years, but what we observe today at the genetic level is simply the net result of all these fluctuations.

In conclusion, climatic change during the Early to Late Pleistocene had a profound impact on genetic structure within Midday gerbil. The present distribution of this species was best explained by prolonged periods of isolation, possibly as a result of Pleistocene glacial cycles and subsequent postglacial expansion into the formerly glaciated areas. Meanwhile, we assume that the present-day distribution of Midday gerbil stems directly from postglacial colonization.

The analysis of more variable nuclear markers, such as microsatellites, would provide very useful information to ascertain present demographic trends and to associate them to the historical events inferred from mtDNA analyses.

ACKNOWLEGEMENTS. This project was funded by the project of Natural Science Foundation of China (NSFC, No. 30370215), the International Cooperation Project of National Natural Science Foundation of China (No. 30611120127), and the Talent Cultivation Project of Anhui University. We thank Y.X. Hou, X.L. Ning for their help to collect specimens in the field. We thank Drs X. Wan, S.T. Zan, Y.Y. Zhang, Y.J. Xing, and C.L. Chen for their review of manuscript.

\section{References}

Avise J.C. 2000. Phylogeography: the History and Formation of Species. Cambridge: Harvard University Press.
$446 \mathrm{p}$.

Avise J.C., Arnold J., Ball R.M., Bermingham E., Lamb T., Neigel J.E., Reeb C.A. \& Saunders N.C. 1987. Intraspecific phylogeography: the mitochondrial DNA bridge between population genetics and systematics // Annual Review of Ecology and Systematics. Vol.18. P.489-522.

Bibb M.J., VanEtten R.A., Wright C.T., Walberg M.W. \& Clayton D.A. 1981. Sequences and gene organization of mouse mitochondrial DNA // Cell. Vol.26. No.2. P.167180.

Bos D.H. \& Sites J.W. 2001. Phylogeography and conservation genetics of the Columbia spotted frog (Rana luteiventris; Amphibia, Ranidae) // Molecular Ecology. Vol.10. No.6. P.1499-1513.

Brant S.V. \& Orti G. 2003. Phylogeography of the northern short-tailed shrew, Blarina brevicauda (Insectivora: Soricidae): past fragmentation and postglacial recolonization // Molecular Ecology. Vol.12. No.6. P.1435-1449.

Conroy C.J. \& Cook J.A. 2000. Phylogeography of a postglacial colonizer: Microtus longicaudus (Rodentia: Muridae) // Molecular Ecology. Vol.9. No.2. P.165-175.

Edward S.V. \& Beerli P. 2000. Perspective: gene divergence, population divergence, and the variance in coalescence time in phylogeographic studies // Evolution. Vol.54. No.6. P.1839-1854.

Excoffier L., Laval G. \& Schneider S. 2005. Arlequin (Version 3.01). An Integrated Software Package for Population Genetics Data Analysis. Computational and Molecular Population Genetics Lab (CMPG), Institute of Zoology University of Berne.

Ernesto R., Inigo M.S., Gabriela P.O. \& Mario G.P. 2006. Phylogeography of Pseudacris regilla (Anura: Hylidae) in western North America, with a proposal for a new taxonomic rearrangement // Molecular Phylogenetics and Evolution. Vol.39. No.2. P.293-304.

Fu Y.X. 1997. Statistical tests of neutrality of mutations against population growth, hitchhiking and background selection // Genetics. Vol.147. No.2. P.915-925.

Galbreath K.E. \& Cook J.A. 2004. Genetic consequences of Pleistocene glaciations for the tundra vole (Microtus oeconomus) in Beringia // Molecular Ecology. Vol.13. No.1. P.135-148.

Hewitt G.M. 1999. Post-glacial re-colonization of European biota// Biological Journal of the Linnean Society. Vol.68. No.1-2. P.87-112.

Hewitt G. M. 2000. The genetic legacy of the Quaternary Ice ages // Nature. Vol.405. No.6788. P.907-913.

Herron M.D., Waterman J.M. \& Parkinson C.L. 2005. Phylogeny and historical biogeography of African ground squirrels: the role of climate change in the evolution of Xerus // Molecular Ecology. Vol.14. No.9. P.2773-2788.

Kocher T.D., Conroy J.A., McKay K.R. \& Stauffer J.R. 1993. Similar morphologies of cichlid fish in lakes Tanganyika and Malawi are due to convergence// Molecular Phylogenetics and Evolution. Vol.2. No.2. P.158-165.

Kumar S., Tamura K. \& Nei M. 2004. MEGA3: Integrated software for molecular evolutionary genetics analysis and sequence alignment // Briefings in Bioinformatics. Vol.5. No.2. P.150-163.

Kuhner M.K., Yamato J. \& Felsenstein J. 1998. Maximum likelihood estimation of population growth rates based 
on the coalescent // Genetics. Vol.149. No.1. P.429-434.

Li H., Meng S.J., Men Z.M., Fu Y.X. \& Zhang Y.P. 2003. Genetic diversity and population history of golden monkeys (Rhinopithecus roxellana) // Genetics. Vol.164. No.1. P.269-275.

Li M., Wei F.W. \& Feng Z.J. 2005. Mitochondrial phylogeography and subspecific variation in the red panda (Ailurus fulgens): Implications for conservation // Molecular Biology and Evolution. Vol.36. No.1. P.78-89.

Li J.Y., Wang K.Z., Li Y.P., Sun G.H. Chu C.H., Li L.Q. \& Zhu Z.X. 2006. Geomorphological features, crustal composition and geological evolution of the Tianshan Mountains // Geological Bulletin of China. Vol.25. No.8. P.895909 [in Chinese].

Luo Z.X., Chen W. \& Gao W. 2000. Fauna Sinica, Mammalia. Vol. 6, Rodentia. Part III, Cricetidae. Beijing: Science Press. 1334 p. [in Chinese].

Ma Y., Wang F.G., Jin S.K. \& Li S.H. 1987. Glires (Rodents and Lagomorphs) of Northern Xinjiang and Their Zoogeographical Distribution. Beijing: Science Press. 274 p. [in Chinese].

Mahmut H., Masuda R., Onuma M., Takahashi M., Nagate J., Suzuki M. \& Ohtaishi N. 2002. Molecular phylogeography of the Red Deer (Cervus elaphus) population in Xinjiang of China: comparison with other Asian, European, and North American populations // Zoological Sciences. Vol.19. No.4. P.485-495.

Nei M. \& Li W.H. 1979. Mathematical model for studying genetic variation in terms of restriction endonucleases // Proceeding of the National Academy of Science. Vol.76. No.10. P.5269-5273.

Oshida T., Aramov A., Yanagawa H. \& Masuda R. 2005. Phylogeography of the Russian flying squirrel (Pteromys volans): implication of refugia theory in arboreal small mammals of Eurasia // Molecular Ecology. Vol.14. No.4. P.1191-1196.

Pierpaoli M., Riga F., Trocchi V. \& Randi E. 1999. Species distinction and evolutionary relationship of the Italian hare (Lepus corsicanus) as described by mitochondrial DNA sequencing // Molecular Ecology. Vol.8. No.11. P.1805-1817.

Pielou E.C. 1991. After the Ice Age: the Return of Life to Glaciated North America. Chicago: University of Chicago Press. 376 p.

Qu Y.H., Ericson P.G.P., Lei F.M. \& Li S.H. 2005. Postglacial colonization of the Tibetan Plateau inferred from the matrilineal genetic structure of the endemic red-necked snow finch, Pyrgilauda ruficollis // Molecular Ecology. Vol.14. No.6. P.1767-1781.
Roslin T. 2001. Spatial population structure in a patchily distributed beetle // Molecular Ecology. Vol.10. No.4. P.823-837.

Rogers A.R. \& Harpending H. 1992. Population growth makes waves in the distribution of pairwise genetic differences // Molecular Biology and Evolution. Vol.9. No.3. P.552-569.

Sambrook J., Fritsch E.F. \& Maniatis T. 1989. Molecular Cloning: A Laboratory Manual. Second Edition. New York: Cold Spring Harbor Laboratory Press.

Saccone C., Lanave C., Pesole G. \& Sbisa E. 1993. Peculiar features and evolution of mitochondrial genome in mammals // DiMauro S. \& Wallace D. (eds.). Mitochondrial DNA in Human Pathology. New York: Raven Press. P.27-37.

Steele C.A., Carstens B.C., Storfer A. \& Sullivan J. 2005. Testing hypotheses of. speciation timing in Dicamptodon copei and Dicamptodon aterrimus (Caudata: Dicamptodontidae) // Molecular Biology and Evolution. Vol.36. No.1. P.90-100.

Taberlet P. 1996. The use of mitochonodrial DNA control region sequencing in conservation biology // Smith T.B. \& Wayne R.K. (eds.). Molecular Genetic Approaches in Conservation. New York: Oxford University Press. P.125-142.

Thompson J.D., Gibson T.J., Plewniak F., Jeanmougin F. \& Higgins D.G. 1997. The Clustal X windows interface: flexible strategies for multiple sequence alignment aided by quality analysis tools // Nucleic Acids Research. Vol.25. No.24. P.4876-4882.

Xia X. \& Xie Z. 2001. DAMBE: software package for data analysis in molecular biology and evolution // Journal of Heredity. Vol.92. No.4. P.371-373.

Zhang D., Fengquan L. \& Jianmin B. 2000. Eco-environmental effects of the Qinghai-Tibet Plateau uplift during the Quaternary in China // Environmental Geology. Vol.39. No.12. P.1352-1358.

Zheng X.G., Arbogast B.S. \& Kenagy G.J. 2003. Historical demography and genetic structure of sister species: deermice (Peromyscus) in the North American temperate rain forest // Molecular Ecology. Vol.12. No.3. P.711-724.

Zhou L.Z., Ma Y. \& Li D.Q. 2001. Spatial distribution patterns of Chinese gerbils (Gerbillinae) in relation to environmental factors // Acta Zoologica Sinica. Vol.47. No.6. P.616-624 [in Chinese].

Zhou L.Z., Ma Y. \& Ye X.D. 2002. Distribution of glires in arid regions of China // Acta Zoologica Sinica. Vol.48. No.2. P.183-194 [in Chinese]. 